\title{
Comparison of Two Reef Sites on the North Coast of Jamaica over a 15-Year Period
}

\author{
M. James C. Crabbe1,2 \\ ${ }^{1}$ Department of Zoology, University of Oxford, Oxford, UK \\ ${ }^{2}$ Institute for Biomedical and Environmental Science and Technology, Department of Life Sciences, University \\ of Bedfordshire, Luton, UK \\ Email: james.crabbe@zoo.ox.ac.uk,james.crabbe@beds.ac.uk
}

Received 23 October 2015; accepted 1 March 2016; published 4 March 2016

Copyright (C) 2016 by author and Scientific Research Publishing Inc.

This work is licensed under the Creative Commons Attribution International License (CC BY).

http://creativecommons.org/licenses/by/4.0/

(c) (i) Open Access

\section{Abstract}

This paper compares two reef sites near Discovery Bay, Jamaica, Dairy Bull and Dancing Lady, from 2000 to 2015. At Dairy Bull reef, with low macroalgal cover (8\% in 2002 falling to $1 \%$ in 2015) and significant number of Diadema antillarum urchins (c. $\left.5 \mathrm{~m}^{-2}\right)$, live coral cover increased from $13 \% \pm 5 \%$ in 2006 after the bleaching event in 2005 , to $31 \% \pm 7 \%$ in 2008 , while live Acropora cervicornis increased from $2 \% \pm 2 \%$ in 2006 to $28 \% \pm 5 \%$ in 2015 . Coral cover levels were at least maintained until 2015, owing mostly to a slight increase in $A$. cervicornis. Dancing Lady reef however was dominated by macroalgae throughout this period (cover of c. $76 \% \pm 7 \%$ ), with no $D$. antillarum and showed little decrease in the already low $(6 \% \pm 1 \%)$ coral cover in 2005 . Growth rates for Siderastrea siderea were similar for both sites $\left(7 \mathrm{~mm} \cdot \mathrm{yr}^{-1}\right)$, while growth rates of $A$. cervicornis and $A$. palmata were $120.0 \pm 30 \mathrm{~mm} \cdot \mathrm{yr}^{-1}$ and $71.0 \pm 29 \mathrm{~mm} \cdot \mathrm{yr}^{-1}$ respectively at Dairy Bull in 2015. At Dancing Lady reef, A. cervicornis colonies which were present from 2003 to 2005 had disappeared in 2006, possibly as a result of the mass bleaching event. It appears that $A$. cervicornis was the most impacted species during the 2005 bleaching event, but was also the species that recovered fastest after its decline at Dairy Bull.

\section{Keywords}

Benthic Cover, Coral Growth Rates, Reef, Bleaching, Dairy Bull, Diadema, Discovery Bay, Climate Change

\section{Introduction}

Current challenges to coral reef sustainability include overfishing, destructive fishing practices, coral bleaching, 
ocean acidification, sea-level rise, crown-of-thorns starfish outbreaks in the Indo-Pacific regions, algal blooms, agricultural run-off, coastal and resort development, marine pollution, increasing prevalence of coral diseases, invasive species and hurricane/cyclone damage. The fringing reefs around Discovery Bay in Jamaica constitute one of the best documented areas of declining coral cover in the Caribbean [1], where loss of corals and macroalgal domination has been due to hurricanes [2] [3], overfishing [4] [5], die-off of the long-spined sea urchin Diadema antillarum in 1983-1984 [6], and coral disease [7]. The fringing reefs around Discovery Bay have seen a number of climate-related challenges in recent years, notably several hurricanes [3] [8] [9] as well as a mass bleaching event in the Caribbean in 2005 [10]-[12]. Nutrient enrichment does not appear to have been a causal factor in the development of the reef macroalgal communities [13].

Maintaining coral reef populations in the face of large-scale degradation and phase-shifts on reefs depends critically on coral recruitment [14] [15], maintenance of grazing fish and urchin populations [16], clade of symbiotic zooxanthellae [17] and management of human activities related to agricultural land use and coastal development [18] [19]. Declining coral cover also leads to losses in fish biodiversity in marine reserves [10].

Dairy Bull reef has for several years been the fringing reef with the highest coral cover in the Discovery Bay area [20]. After the 2005 bleaching event there was a major loss of live coral cover, particularly of A. cervicornis [8] [21]. Dancing Lady reef in the 1970s had colonies of A. palmata and A. cervicornis growing in close proximity to the reef crest, while in deeper water there was a similar picture for Orbicella annularis and luxurious stands of Agaricia sp. [22] [23] (P. Dustan, personal communication; [http://reefbuilders.com/2015/01/27/caribbean-coral-reefs-fields-coral/]).

Here, we investigate coral cover and coral growth rates at Dairy Bull and Dancing Lady reefs over a fifteen year period, from 2000 to 2015. These sites were chosen as they potentially represented two alternatives of reef behaviour post-hurricane Allen in 1980 [2], where the latter, but not the former, was dominated by macroalgae.

\section{Materials and Methods}

\section{Sites and Sampling}

Four haphazardly located transects at each site, each transect $15 \mathrm{~m}$ long and separated by at least $5 \mathrm{~m}$, were laid at between 5 - $8.5 \mathrm{~m}$ depth at both Dairy Bull reef $\left(18^{\circ} 28.083^{\prime} \mathrm{N} ; 77^{\circ} 23.302^{\prime} \mathrm{W}\right)$ and Dancing Lady reef $\left(18^{\circ} 28.369 ' \mathrm{~N} ; 77^{\circ} 24.802^{\prime} \mathrm{W}\right)$, near Discovery Bay, Jamaica. GPS coordinates were determined using a hand-held GPS receiver (Model 72, Garmin Ltd.). Corals $2 \mathrm{~m}$ on either side of the transect lines were photographed (using overlapping photographs) for archive information and surface areas measured with flexible tape using SCUBA [3] [24]. Percentage cover was determined for total live coral, individual coral species, and macroalgae from inspection of images. Numbers of Diadema antillarum $\mathrm{m}^{-2}$ along the transects were recorded from inspection of images.

Radial growth rates $\left(\mathrm{mm} \cdot \mathrm{yr}^{-1}\right)$ of the non-branching coral Siderastrea siderea, and linear extension rates (mm· $\mathrm{yr}^{-1}$ ) of branching corals Acropora cervicornis and Acropora palmata were measured and calculated as described previously [3] [24]. Briefly, surface areas were calculated (using a standard formula) from the largest diameter of the coral head, measured with a flexible tape or with vernier callipers, and the diameter at $90^{\circ}$ to that.

This work was conducted during July 15-31 and December 19-30 in 2000, March 26-April 19 2002, March 18-April 10 2003, July 23-August 21 2004, July 18-August 13 2005, April 11-18 2006, December 30 2006January 6 2007, July 30-August 16 2008, July 27-August 8 2009, April 14-16 2010, July 30-August 2 2012, and February 2-5 in 2015.

Computer digital image analysis was undertaken using the UTHSCSA (University of Texas Health Science Center, San Antonio, Texas, USA) Image Tool software [24], to separately check measurements of coral radial growth rates. One or two-factor ANOVA was used to compare coral data between sites; \pm error values represent standard errors of the data. Post-hoc power analyses were conducted according to Leith [25].

\section{Results}

Figure 1 shows mean percentage cover + or \pm 1 S.E. of total live coral, and species Acropora cervicornis, Porites astreoides, Acropora palmata, Siderastrea siderea, Diploria strigosa, macroalgae and numbers of Diadema antillarum $\mathrm{m}^{-2}$ at (a), Dairy Bull reef and (b), Dancing Lady reef from 2002 to 2012. At Dairy Bull reef, 


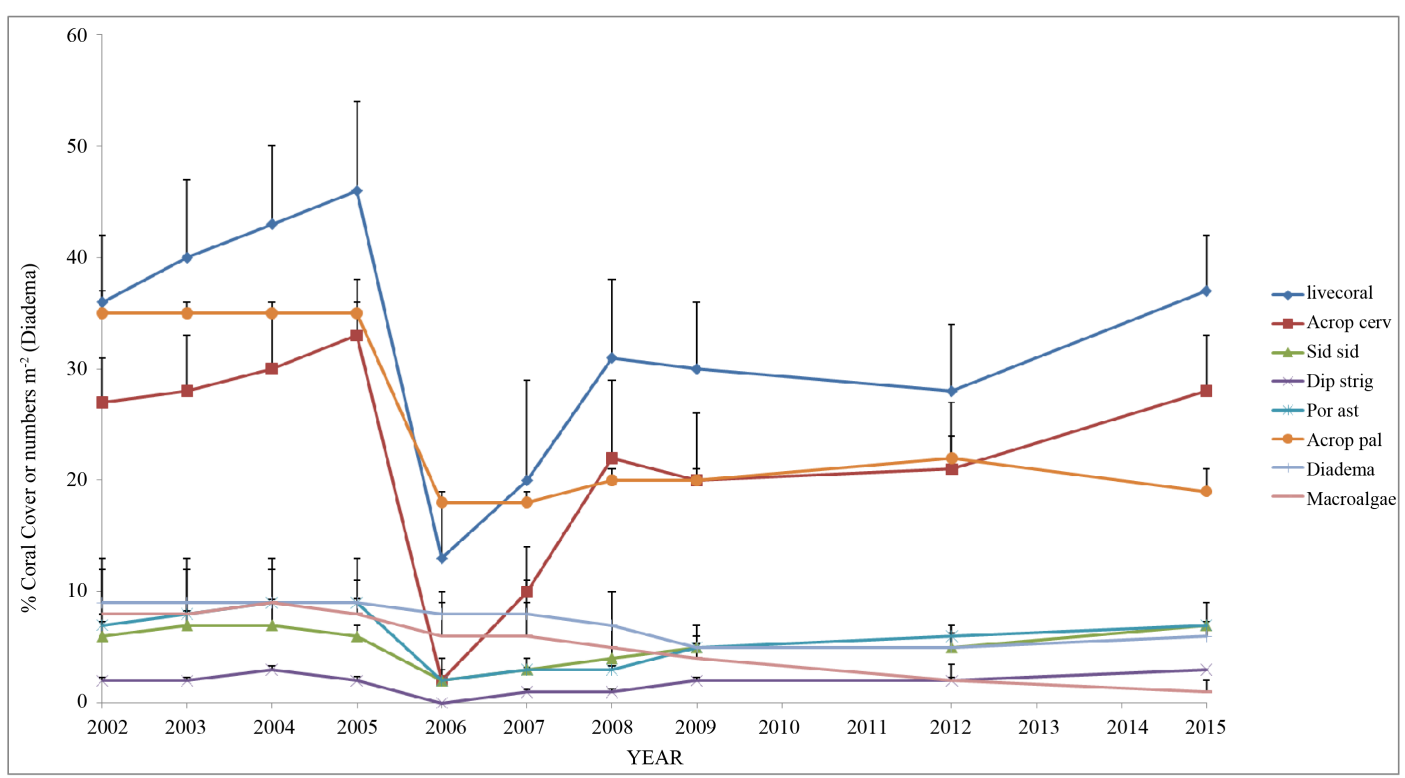

(a)

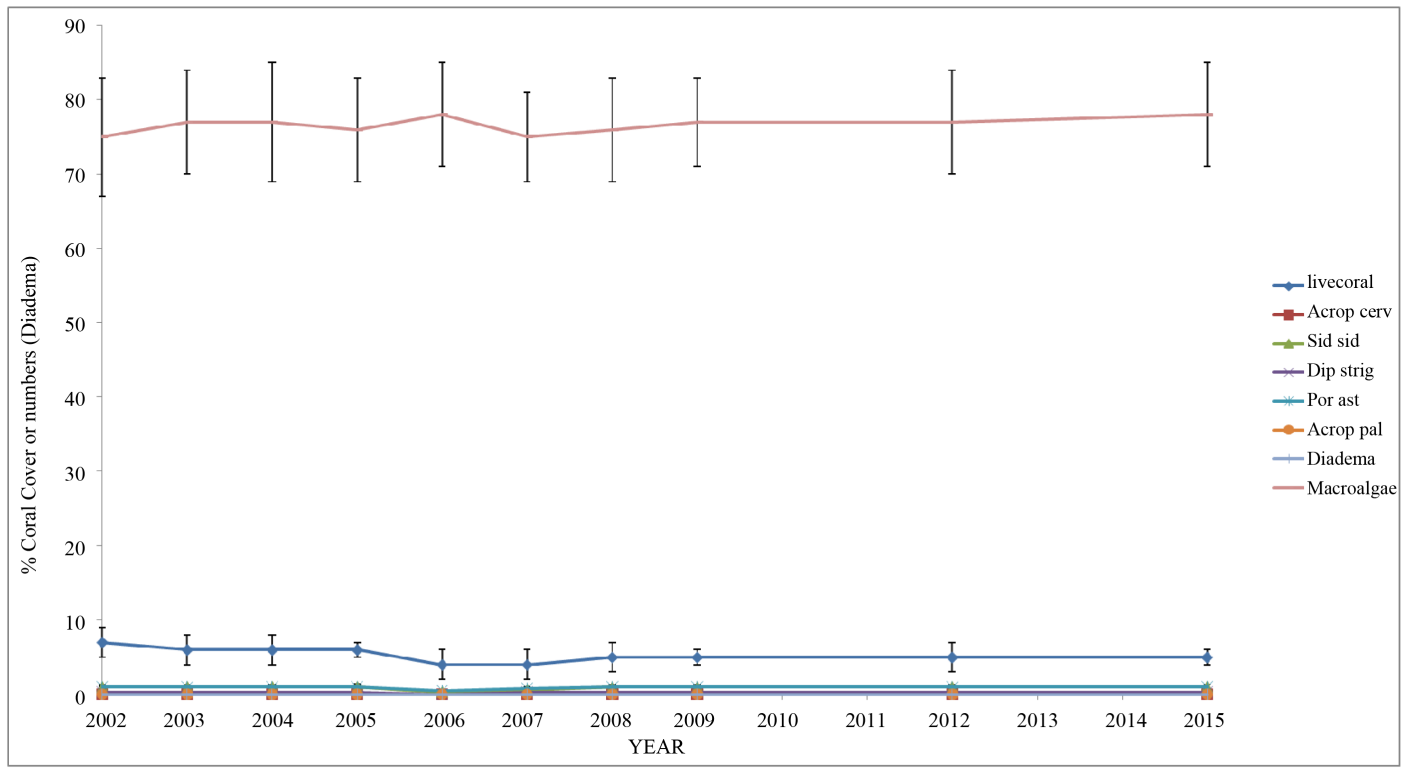

(b)

Figure 1. Cover of live coral, individual coral species, macroalgae and numbers of Didema antillarum at (a), the Dairy Bull reef site and (b), the Dancing Lady reef site from 2002-2015. Total live coral ( $\downarrow)$; Acropora cer-

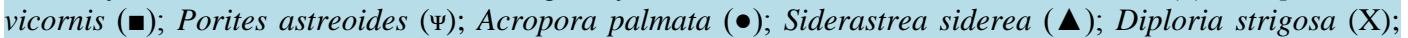
Diadema antillarum numbers $\mathrm{m}^{-2}(+)$; Macroalgae $(-)$. Values are shown +1 S.E. in (a), and \pm 1 S.E. in (b).

live coral cover increased from 13\% $\pm 5 \%$ in 2006 after the bleaching event in 2005, to 35\% \pm 6\% in 2015, while live A. cervicornis increased from $2 \% \pm 2 \%$ in 2006 to $28 \% \pm 5 \%$ in 2015 . Coral cover levels were at least maintained until 2015, owing mostly to a slight increase in A. cervicornis. Dancing Lady reef however was dominated by macroalgae throughout this period (cover of c. $76 \% \pm 10 \%$ ), and showed little decrease in the already low $(6 \% \pm 1 \%)$ coral cover in 2005 owing to the bleaching event later that year. Diadema at Dairy Bull varied from between $5-9 \mathrm{~m}^{-2}$, while $<1 \mathrm{~m}^{-2}$ were observed at Dancing Lady reef. Decreases in live coral cover, A. cervicornis and A. palmata were significant at Dairy Bull in 2006 and 2007 (p < 0.02, power > 0.65 for each). The slight decrease in live coral cover at Dancing Lady in 2006 was not significant.

Table 1 shows radial growth rates $\left(\mathrm{mm} \cdot \mathrm{yr}^{-1}\right)$ of the non-branching coral S. siderea, and linear extension rates 
Table 1. Radial growth rates $\left(\mathrm{mm} \cdot \mathrm{yr}^{-1}\right)$ of the non-branching coral Siderastrea siderea, and linear extension rates $\left(\mathrm{mm} \cdot \mathrm{yr}^{-1}\right)$ of branching corals Acropora cervicornis and Acropora palmata calculated on a annual basis from 2000-2003, 2003-2005, 2005-2008, 2008-2012 and 2012-2015 (00-03, 03-05, 05-08, 08-12 and 12-15 respectively), at Dancing Lady (DL) and Dairy Bull (DB). Values represent growth rates \pm standard errors; $n=5$ for each species. $\mathrm{nm}$, not measurable in sufficient numbers for analysis.

\begin{tabular}{|c|c|c|c|c|c|c|c|c|c|c|c|}
\hline \multicolumn{12}{|c|}{ SITE } \\
\hline & \multirow[b]{2}{*}{ Year } & \multicolumn{5}{|c|}{ DL } & \multicolumn{5}{|c|}{ DB } \\
\hline & & $00-03$ & 03-05 & 05-08 & $08-12$ & $12-15$ & 00-03 & 03-05 & 05-08 & 08-12 & $12-15$ \\
\hline \multirow{3}{*}{ Species } & $\begin{array}{l}\text { Acropora } \\
\text { cervicornis }\end{array}$ & $\mathrm{nm}$ & $85.0 \pm 25$ & $\mathrm{~nm}$ & $\mathrm{~nm}$ & $\mathrm{~nm}$ & $109.0 \pm 27$ & $111.0 \pm 30$ & $146.0 \pm 40$ & $140.0 \pm 35$ & $120.0 \pm 30$ \\
\hline & $\begin{array}{c}\text { Acropora } \\
\text { palmata }\end{array}$ & $\mathrm{nm}$ & $\mathrm{nm}$ & $\mathrm{nm}$ & $\mathrm{nm}$ & $\mathrm{nm}$ & $90.0 \pm 50$ & $88.0 \pm 45$ & $90.0 \pm 40$ & $70.0 \pm 30$ & $71.0 \pm 29$ \\
\hline & $\begin{array}{l}\text { Siderastrea } \\
\text { siderea }\end{array}$ & $7.3 \pm 1.8$ & $7.0 \pm 2.1$ & $7.1 \pm 1.8$ & $7.2 \pm 2.3$ & $7.1 \pm 2.9$ & $7.2 \pm 3.3$ & $7.1 \pm 2.9$ & $7.5 \pm 3.2$ & $7.5 \pm 2.8$ & $7.4 \pm 3.0$ \\
\hline
\end{tabular}

(mm. $\mathrm{yr}^{-1}$ ) of branching corals A. cervicornis and A. palmata calculated on a annual basis over a 15-year period starting from 2000, at Dancing Lady and Dairy Bull reefs. The growth rates are largely similar to those reported by Huston [26]. Where growth rates were higher, they tended to be higher at Dairy Bull reef, but the differences were not significant. At Dancing Lady reef, A. cervicornis colonies which were measurable from 2003-2005 had disappeared in 2006, possibly as a result of the mass bleaching event.

\section{Discussion}

The Jamaican reefs are subject to a number of both acute and chronic stressors, from Hurricane Allen in 1980, through the die-off of Diadema antillarum in the early 1980s to continuing overfishing and coastal development, which produce almost constant impacts to the reefs. By far the major acute influence on the corals over the study period was the mass bleaching event of late 2005 [12]. What is apparent from the present study is that despite the chronic and acute disturbances over the 15-year period, Dairy Bull has managed to survive and maintain its coral cover, unlike the predominantly macroalgal Dancing Lady reef. The recovery of Dairy Bull reef can be attributed, at least in part, to the recovery of Acropora sp. at that location. Interestingly, a bleaching event in 1983 on the shallow reefs in the Java Sea resulted in the loss of branching species in the genera Acropora and Pocillopora [27]. Five years later, the community structure had largely recovered, although coral cover was not as high as formerly.

Another difference between the two reefs is their rugosity; that of Dairy Bull ( $2.3 \pm 0.16)$ is nearly twice that of Dancing Lady (1.3 \pm 0.15 ) [28]. Rugosity has been found important for predicting intra-habitat variation in coral reef fish assemblages [29] and loss of architectural complexity in Caribbean reefs due to climate change appears to be linked to physical impacts, such as hurricanes and bio-erosion [30]. Certainly hurricane Allen in 1980, followed closely by the die-off of Diadema antillarum, produced major physical changes to the Jamaican reefs [2], including loss of branching corals. The presence of Diadema at Dairy Bull is another important factor, as Diadema recovery has reduced macroalgal cover and increased abundance of juvenile corals on Jamaican reefs [31] [32].

\section{Acknowledgements}

I thank the Earthwatch Institute and the Royal Society for funding, Dayne Buddo, Anthony Downes, Peter Gayle, Daniel Scarlett, Denise Henry, and the staff of the Discovery Bay Marine Laboratory for their invaluable help and assistance, and volunteers for their help underwater during this project.

\section{References}

[1] Jackson, J.B.C., Donovan, M.K., Cramer, K.L. and Lam, V.V., Eds. (2014) Status and Trends of Caribbean Coral Reefs: 1970-2012. Global Coral Reef Monitoring Network, IUCN, Gland, Switzerland.

[2] Woodley, J.D., Chornesky, E.A., Clifford, P.A., Jackson, J.B.C., Kaufman, L.S., Knowlton, N., Lang, J.C., Pearson, 
M.P., Porter, J.W., Rooney, M.C., Rylaarsdam, K.W., Tunnicliffe, V.J., Wahle, C.M., Wulff, J.L., Curtis, A.S.G., Dallmeyer, M.D., Jupp, B.P., Koehl, M.A.R., Neigel, J. and Sides, E.M. (1981) Hurricane Allen’s Impact on Jamaican Coral Reefs. Science, 214, 749-755. http://dx.doi.org/10.1126/science.214.4522.749

[3] Crabbe, M.J.C., Mendes, J.M. and Warner, G.F. (2002) Lack of Recruitment of Non-Branching Corals in Discovery Bay Is Linked to Severe Storms. Bulletin of Marine Science, 70, 939-945.

[4] Jackson, J.B.C. (1997) Reefs since Columbus. Proceedings of the $8^{\text {th }}$ International Coral Reef Symposium, 1, 97-106. http://dx.doi.org/10.1007/s003380050238

[5] Hawkins, J.P. and Roberts, C.M. (2004) Effects of Artisanal Fishing on Caribbean Coral Reefs. Conservation Biology, 18, 215-226. http://dx.doi.org/10.1111/j.1523-1739.2004.00328.x

[6] Hughes, T.P. (1994) Catastrophes, Phase Shifts and Large-Scale Degradation of a Caribbean Coral Reef. Science, 265, 1547-1551. http://dx.doi.org/10.1126/science.265.5178.1547

[7] Aronson, R.B. and Precht, W.F. (2001) Evolutionary Paleoecology of Caribbean Coral Reefs. In: Allmon, W.D. and Bottjer, D.J., Eds., Evolutionary Paleoecology: The Ecological Context of Macroevolutionary Change, Columbia University Press, New York, 171-233.

[8] Crabbe, M.J.C. (2009) Scleractinian Coral Population Size Structures and Growth Rates Indicate Coral Resilience on the Fringing Reefs of North Jamaica. Marine Environmental Research, 67, 189-198. http://dx.doi.org/10.1016/j.marenvres.2009.01.003

[9] Mallela, J. and Crabbe, M.J.C. (2009) Hurricanes and Coral Bleaching Linked to Changes in Coral Recruitment in Tobago. Marine Environmental Research, 68, 158-162. http://dx.doi.org/10.1016/j.marenvres.2009.06.001

[10] Jones, G.P., McCormick, M.I., Srinivasan, M. and Eagle, J.V. (2004) Coral Decline Threatens Fish Biodiversity in Marine Reserves. Proceedings of the National Academy of Sciences USA, 101, 8251-8253. http://dx.doi.org/10.1073/pnas.0401277101

[11] Jones, L., Alcolado, P.M., Cala, Y., Cobián, D., Coelho, V., Hernández, A., Jones, R., Mallela, J. and Manfrino, C. (2008) The Effects of Coral Bleaching in the Northern Caribbean and Western Atlantic. In: Wilkinson, C. and Souter, D., Eds., Status of Caribbean Coral Reefs after Bleaching and Hurricanes in 2005, Global Coral Reef Monitoring Network, and Reef and Rainforest Research Centre, Townsville, 73-83.

[12] Eakin, C.M., Morgan, J.A., Heron, S.F., Smith, T.B., Liu, G., Alvarez-Filip, L., Baca, B., Bartels, E., Bastidas, C., Bouchon, C., Brandt, M., Bruckner, A., Bunkley-Williams, L., Cameron, A., Causey, B.D., Chiappone, M., Christensen, T.R.L., Crabbe, M.J.C., Day, O., de la Guardia, E., Díaz-Pulido, G., DiResta, D., Gil-Agudelo, D.L., Gilliam, D., Ginsburg, R., Gore, S., Guzman, H.M., Hendee, J.C., Hernández-Delgado, E.A., Husain, E., Jeffrey, C.F.G., Jones, R.J., Jordán-Dahlgren, E., Kaufman, L., Kline, D.I., Kramer, P., Lang, J.C., Lirman, D., Mallela, J., Manfrino, C., Maréchal, J.-P., Marks, K., Mihaly, J., Miller, W.J., Mueller, E.M., Muller, E., Orozco Toro, C.A., Oxenford, H.A., Ponce-Taylor, D., Quinn, N., Ritchie, K.B., Rodríguez, S., Rodríguez Ramírez, A., Romano, S., Samhouri, J.F., Sánchez, J.A., Schmahl, G.P., Shank, B., Skirving, W.J., Steiner, S.C.C., Villamizar, E., Walsh, S.M., Walter, C., Weil, E., Williams, E.H., Roberson, W.K. and Yusuf, Y. (2010) Caribbean Corals in Crisis: Record Thermal Stress, Bleaching, and Mortality in 2005. PLOS ONE, 5, e13969. http://dx.doi.org/10.1371/journal.pone.0013969

[13] Greenaway, A.M. and Gordon-Smith, D.-A. (2006) The Effects of Rainfall on the Distribution of Inorganic Nitrogen and Phosphorus in Discovery Bay, Jamaica. Limnology and Oceanography, 51, 2206-2220. http://dx.doi.org/10.4319/lo.2006.51.5.2206

[14] Hughes, T.P. and Tanner, J.E. (2000) Recruitment Failure, Life Histories and Long-Term Decline of Caribbean Corals. Ecology, 81, 2250-2263. http://dx.doi.org/10.1890/0012-9658(2000)081[2250:RFLHAL]2.0.CO;2

[15] Coles, S.L. and Brown, E.K. (2007) Twenty-Five Years of Change in Coral Coverage on a Hurricane Impacted Reef in Hawai'i: The Importance of Recruitment. Coral Reefs, 26, 705-717. http://dx.doi.org/10.1007/s00338-007-0257-3

[16] Mumby, P.J., Hastings, A. and Edwards, H.J. (2007) Thresholds and the Resilience of Caribbean Coral Reefs. Nature, 450, 98-101. http://dx.doi.org/10.1038/nature06252

[17] Stat, M., Morris, E. and Gates, R.D. (2008) Functional Diversity in Coral-Dinoflagellate Symbiosis. Proceedings of the National Academy of Sciences of the United States of America, 105, 9256-9261. http://dx.doi.org/10.1073/pnas.0801328105

[18] Mora, C. (2008) A Clear Human Footprint in the Coral Reefs of the Caribbean. Proceedings of the Royal Society BBiological Sciences, 275, 767-773. http://dx.doi.org/10.1098/rspb.2007.1472

[19] Curnick, D.J., Head, C., Huang, D., Crabbe, M.J.C., Gollock, M., Hoeksema, B., Johnson, K.G., Jones, R., Koldeway, H.J., Obura, D.O., Rosen, B.R., Smith, D.J., Taylor, M.L., Turner, J.R., Wren, S. and Redding, D.W. (2015) Setting Evolutionary-Based Conservation Priorities for a Phylogenetically Data-Poor Taxonomic Group (Scleractinia). Animal Conservation, 18, 303-312. http://dx.doi.org/10.1111/acv.12185

[20] Idjadi, J.A., Lee, S.C., Bruno, J.F., Precht, W.F., Allen-Requa, L. and Edmunds, P.J. (2006) Rapid Phase-Shift Rever- 
sal on a Jamaican Coral Reef. Coral Reefs, 25, 209-211. http://dx.doi.org/10.1007/s00338-006-0088-7

[21] Quinn, N.J. and Kojis, B.L. (2008) The Recent Collapse of a Rapid Phase-Shift Reversal on a Jamaican North Coast Reef after the 2005 Bleaching Event. International Journal of Tropical Biology, 56, 149-159.

[22] Dustan, P. (1975) Growth and Form in the Reef-Building Coral Montastrea annularis. Marine Biology, 33, $101-107$. http://dx.doi.org/10.1007/BF00390714

[23] Dustan, P., Doherty, O. and Pardede, S. (2013) Digital Reef Rugosity Estimates Coral Reef Habitat Complexity. PLoS ONE, 8, e57386. http://dx.doi.org/10.1371/journal.pone.0057386

[24] Crabbe, M.J.C. and Smith, D.J. (2005) Sediment Impacts on Growth Rates of Acropora and Porites Corals from Fringing Reefs of Sulawesi, Indonesia. Coral Reefs, 24, 437-441. http://dx.doi.org/10.1007/s00338-005-0004-6

[25] Leith, R.V. (2007) Post-Hoc Power: Tables and Commentary. Technical Report No. 378, University of Iowa, Iowa City.

[26] Huston, M. (1985) Variation of Coral Growth Rates with Depth at Discovery Bay, Jamaica. Coral Reefs, 4, 19-25. http://dx.doi.org/10.1007/BF00302200

[27] Brown, B.E. and Suharsono (1990) Damage and Recovery of Coral Reefs Affected by El Nino Related Seawater Warming in the Thousand Islands, Indonesia. Coral Reefs, 8, 163-170. http://dx.doi.org/10.1007/BF00265007

[28] Crabbe, M.J.C. (2010) Topography and Spatial Arrangement of Reef-Building Corals on the Fringing Reefs of North Jamaica May Influence Their Response to Disturbance from Bleaching. Marine Environmental Research, 69, 158-162. http://dx.doi.org/10.1016/j.marenvres.2009.09.007

[29] Graham, N.A.J., Jennings, S., MacNeil, M.A., Mouillot, D. and Wilson, S.K. (2015) Predicting Climate-Driven Regime Shifts versus Rebound Potential in Coral Reefs. Nature, 518, 94-97. http://dx.doi.org/10.1038/nature14140

[30] Alvarez-Filip, L., Gill, J.A., Dulvy, N.K., Perry, A.L., Watkinson, A.R. and Coté, I.M. (2011) Drivers of Region-Wide Declines in Architectural Complexity on Caribbean Reefs. Coral Reefs, 30, 1051-1060. http://dx.doi.org/10.1007/s00338-011-0795-6

[31] Edmunds, P.J. and Carpenter, R.C. (2001) Recovery of Diadema antillarum Reduces Macroalgal Cover and Increases Abundance of Juvenile Corals on a Caribbean Reef. Proceedings of the National Academy of Sciences of the United States of America, 98, 5067-5071. http://dx.doi.org/10.1073/pnas.071524598

[32] Crabbe, M.J.C. (2016) The Impact of Climate Change and the Environment on Coral Growth. In: Goffredo, S. and Dubinsky, Z., Eds., The Cnidaria, Past, Present and Future: The World of Medusa and Her Sisters, Springer Verlag, Cham. (In Press) 